\title{
Prevalence of anemia and associated factors among indigenous children in Brazil: results from the First National Survey of Indigenous People's Health and Nutrition
}

Maurício S Leite ${ }^{1}$, Andrey M Cardoso ${ }^{2}$, Carlos EA Coimbra Jr², James R Welch², Silvia A Gugelmin ${ }^{3}$, Pedro Cabral I Lira ${ }^{4}$, Bernardo L Horta ${ }^{5}$, Ricardo Ventura Santos ${ }^{2,6}$ and Ana Lúcia Escobar ${ }^{7}$

\begin{abstract}
Background: Anemia is the most prevalent nutritional deficiency globally, affecting about a quarter of the world population. In Brazil, about one-fifth of children under five years of age are anemic. Previous case studies indicate prevalence rates much higher among indigenous peoples in the country. The First National Survey of Indigenous People's Health and Nutrition in Brazil, conducted in 2008-2009, was the first survey based on a nationwide representative sample to study the prevalence of anemia and associated factors among indigenous children in Brazil.

Methods: The survey assessed the health and nutritional status of indigenous children $<5$ years of age based on a representative sample of major Brazilian geopolitical regions. A stratified probabilistic sampling was carried out for indigenous villages. Within villages, children $<5$ years of age in sampled households were included in the study. Prevalence rates of anemia were calculated for independent variables and hierarchical multivariate analysis were conducted to assess associations.

Results: Evaluation of hemoglobin levels was conducted for 5,397 children ( $88.1 \%$ of the total sample). The overall prevalence of anemia was $51.2 \%$. Higher risk of presenting anemia was documented for boys, lower maternal schooling, lower household socioeconomic status, poorer sanitary conditions, presence of maternal anemia, and anthropometric deficits. Regional differences were observed, with the highest rate being observed in the North.

Conclusions: The prevalence rates of anemia in indigenous children were approximately double than those reported for non-indigenous Brazilian children in the same age group. Similarly notable differences in the occurrence of anemia in indigenous and non-indigenous children have been reported for other countries. Deeper knowledge about the etiology of anemia in indigenous children in Brazil is essential to its proper treatment and prevention.
\end{abstract}

Keywords: Brazil, Indigenous peoples, Health surveys, Nutrition surveys, Health status indicators, Anemia, Child health

\footnotetext{
* Correspondence: welch@ensp.fiocruz.br

Escola Nacional de Saúde Pública, Fundação Oswaldo Cruz, Rua Leopoldo Bulhões 1480, Rio de Janeiro, RJ 21041-210, Brazil

Full list of author information is available at the end of the article
} 


\section{Introduction}

Anemia is considered the most prevalent nutritional deficiency globally, affecting about a quarter of the world population, especially children and women of reproductive age $[1,2]$. In children, anemia can negatively affect cognitive development, school performance, physical growth, and immunity [3-6]. In Brazil, the changing nutritional scenario of children less than five years of age has been evaluated optimistically based on results from national surveys in recent decades, revealing a tendency towards dramatic reductions in the prevalence rates of chronic undernutrition for this age group in all regions of the country [7]. This trend has been attributed to improvements in education levels and family socioeconomic conditions, as well as public investments in infrastructure, health, and sanitation. Nevertheless, similar improvements have not been observed in relation to child anemia in Brazil. According to recent studies, about one-fifth of Brazilian children under five years of age are anemic $[8,9]$.

The few existing studies of anemia among indigenous peoples in Brazil, which are derived from research conducted in specific localized groups, have revealed prevalence rates much higher than those documented for the national population, generally greater than $50-60 \%$ in children under five years of age [10-12]. The discrepancy observed between the prevalence rates of anemia among indigenous and non-indigenous children in Brazil are also documented for other regions of the world, with the burden of disease tending to be much higher among indigenous peoples than their respective national populations [13-16].

Until now there were no population-based studies permitting generalization about the epidemiology of anemia and its principal determinants among indigenous children in Brazil. The First National Survey of Indigenous People's Health and Nutrition in Brazil (henceforth, "National Survey"), conducted in 2008-2009, was the first study of its kind to include a nationwide representative sample of indigenous peoples in the country [17]. One of its main objectives was to understand the contemporary health profile of the nation's indigenous population in terms of diverse socioeconomic and environmental factors. The aim of our paper is to present the results of analyses on the prevalence of anemia and associated factors among indigenous children $\geq 6$ months and $<5$ years of age in Brazil, based on hemoglobin levels measured by the National Survey field teams.

\section{Methods}

The National Survey assessed the health and nutritional status of indigenous children $<5$ years of age in Brazil [17]. A representative sample of four major Brazilian geopolitical regions (North, Northeast, Central-West and
Southeast/South) was obtained by multi-stage sampling, as previously reported [17]. Initially, a stratified probabilistic sampling was carried out of indigenous villages located in the four regions, based on a list of villages in federal indigenous reserves provided by the Brazilian Ministry of Health's National Health Foundation (Fundação Nacional de Saúde - FUNASA) on January 22, 2008. The original list contained 3,995 villages. Excluded for the sampling purposes of the National Survey were 1227 (30.7\%) villages identified by FUNASA as vacated ("desaldeadas"), deactivated, or having less than 31 inhabitants. The sample size for each region was estimated based on the size of its target population, a prevalence of $50 \%$ for all outcomes, a relative precision of $5 \%$, and a confidence level of $95 \%$, according to the methodology proposed by Lemeshow et al. [18]. Taking into account the calculated sample size for each region, Sequential Poisson Sampling criteria were used to select villages for inclusion in the study [19]. The final sample included 123 villages distributed by region as follows: 65 (North), 14 (Central-West), 23 (Northeast), and 21 (South/Southeast).

Subsequently, indigenous households in sampled villages were selected by either census or sample, depending on their estimated populations. Investigation by census (inclusion of all households) was carried out in villages with populations of children $<5$ years and women from 14 to 49 years of age $\leq 150$ individuals. In villages with populations of women and children greater than 150 individuals, households were selected systematically using a predetermined increment without substitution in the event of absence or refusal. Further details on the study methodology have been published elsewhere [17].

In investigated households, the mothers or caretakers of all children $<5$ years of age were interviewed. The instrument contained questions on infant feeding, access to health services, morbidity and nutritional status, the latter of which was clinically evaluated by our teams using anthropometry and hemoglobin, as well as household characteristics $[17,20]$. Sources of household income were classified as "regular" if received monthly or annually (e.g., salaries, pensions, social benefits). Basic birth data were obtained from FUNASA healthcare records, personal documents, or informed by interviewees.

In order to determine hemoglobin levels in infants and children $\geq 6$ months and $<5$ years of age, a single drop of capillary blood was obtained with one-way lancets fitted to an ACCU-CHEK ${ }^{\circ}$ lancing device by Roche (Mannheim, Germany) and analyzed using portable hemoglobinometers, model HemoCue Hb 201+ (Ängelholm, Sweden). Children with hemoglobin levels $<11.0 \mathrm{~g} / \mathrm{dL}$ were considered anemic [3]. Levels $<9.5 \mathrm{~g} / \mathrm{dL}$ were considered indicative of moderate/severe anemia [3]. 
Principal component analysis of reported quantities of 19 durable goods was used to calculate an indicator of socioeconomic condition [17]. Factor scores from the first component, accounting for $19 \%$ of the total variability in the dataset (eigenvalue of 3.56), were applied as weights to the item quantities reported for each household. The sum of these values was then used to classify households in tertiles, based on the combined distribution and considering the four regions, which served as a household goods index.

In initial data analyses, prevalence rates of anemia were calculated according to independent variables (geopolitical region, demographic variables, socioeconomic variables, characteristics of the household environment, and maternal and child characteristics). Estimates were corrected for the complex sampling design of the study. Measures of associations were expressed as prevalence ratios and their corresponding 95\% confidence intervals. Chi-square tests for linear trend were used to evaluate differences in proportions. The prevalence of moderate/ severe anemia was calculated by geopolitical region, even though this outcome was not included separately in the other analyses.

The multivariate analysis followed a hierarchical conceptual framework based on Poisson regression with robust adjustment of the variance for dichotomous outcomes (anemic or not anemic) [21,22]. Geopolitical region was used as a control variable in all levels. Other independent variables entered the analysis at their respective levels in the model. The first and most distal level included child's sex, age and socioeconomic variables (maternal schooling, presence of regular income from salaries or social programs, and household goods index). The second hierarchical level contained variables related to household construction (flooring, walls, and roofing), composition (number of residents and number of children $<5$ years in the household), electricity, and sanitation (location used to defecate, predominant destination of household trash, and source of drinking water). The third level included maternal characteristics (age, number of children ever had, and anemia). Finally, the fourth and most proximal level encompassed child health variables (place of delivery, birth weight, nutritional status, diarrhea during the prior week, and treatment or supplementation with iron sulfate in the prior three months).

The initial step of the multivariate analyses was to select variables with $\mathrm{p}<0.20$ following adjustment for geopolitical region and for variables retained in previous levels, if present. Subsequently, for each level, selected variables were jointly included in the model, controlling for geopolitical region and all variables retained in previous levels, if present. A backward procedure was then used to progressively exclude variables at each level, retaining only those with a significance level of $\mathrm{p}<0.05$. Therefore, in the final model, the prevalence ratios were simultaneously adjusted for variables in the same hierarchical level, those retained in previous levels, and geopolitical region. All analyses were conducted with the program STATA 10.0 (College Station, TX, USA).

\section{Ethics}

The National Survey was authorized by the National Committee on Research Ethics (Comissão Nacional de Ética em Pesquisa - CONEP, authorization number 256/ 2008) and the National Indian Foundation (Fundação Nacional do Índio - FUNAI). Upon arrival at each indigenous community, the research team held meetings with leaders and other community members, during which the objectives and procedures of the study were clearly presented. A Free and Informed Collective Consent form was presented and signed by leaders, as well as other community representatives when indicated to our field teams (indigenous health agents, teachers, etc.). Any particular village, household, parent, or guardian was allowed to decline to participate at any moment of fieldwork.

\section{Results}

Evaluation of hemoglobin levels was conducted for 5,397 children (88.1\% of the planned sample) in 113 villages (91.9\% of sample) and 5,305 households $(93.5 \%$ of sample). The overall prevalence of anemia $(\mathrm{Hb}<11 \mathrm{~g} / \mathrm{dL})$ was $51.2 \%$. Among all geopolitical regions, the highest prevalence was recorded in the North $(66.4 \%)$, followed by the Central-West (51.5\%), South/Southeast (48.0\%) and Northeast (41.1\%) (Table 1). The prevalence of moderate/ severe anemia $(\mathrm{Hb}<9 \mathrm{~g} / \mathrm{dL})$ was $16.4 \%$, distributed by region in the same order as described for anemia: North (25.4\%), Central-West (14.8\%), South/Southeast (15.9\%) and Northeast (10.1\%).

Boys in all age groups had a slightly higher risk of presenting anemia than girls (PR 1.06, $\mathrm{CI}_{95 \%}$ 1.01-1.13) (Table 1). The risk of anemia decreased with increasing age of the child, progressively lowering with each age group. Maternal schooling showed a similar pattern, with lower risk among children whose mothers had ten or more years of schooling. Access to regular income and household goods index in the upper two tertiles also showed a protective effect. Belonging to the first and third tertiles of the household goods index showed the most pronounced contrast, with the former resulting in 1.38 times greater risk $\left(\mathrm{CI}_{95 \%}\right.$ 1.23-1.54) than the latter.

With regard to household and environmental variables (Table 2), the risk of presenting anemia was higher in households with floors made of wood, walls of palm thatch, and roofing of nondurable materials such as canvas, and plastic. Higher risk of anemia was also observed 
Table 1 Prevalence rates of anemia among indigenous children $<\mathbf{6 0}$ months according to geopolitical region, sex, age, and socioeconomic characteristics, First National Survey of Indigenous People's Health and Nutrition, Brazil, 2008-2009

\begin{tabular}{|c|c|c|c|c|}
\hline Characteristic studied & $\mathbf{N}$ & Prevalence (\%) & PR & $\mathrm{Cl} 95 \%$ \\
\hline \multicolumn{5}{|l|}{ Region } \\
\hline Northeast & 1211 & 41.06 & 1.00 & Reference \\
\hline South/Southeast & 765 & 47.95 & 1.17 & $0.95-1.44$ \\
\hline Central-West & 1141 & 51.52 & 1.25 & $1.04-1.51$ \\
\hline North & 2280 & 66.40 & 1.62 & $1.36-1.92$ \\
\hline \multicolumn{5}{|l|}{ Child's sex ${ }^{\dagger}$} \\
\hline Female & 2635 & 49.60 & 1.00 & Reference \\
\hline Male & 2761 & 52.79 & 1.06 & $1.01-1.13$ \\
\hline Child's age (months) $^{\dagger}$ & & & $p=0.000^{*}$ & \\
\hline $6-11$ & 673 & 80.24 & 1.00 & Reference \\
\hline $12-23$ & 1198 & 68.21 & 0.85 & $0.78-0.92$ \\
\hline $24-35$ & 1170 & 48.78 & 0.61 & $0.55-0.67$ \\
\hline $36-47$ & 1239 & 39.42 & 0.49 & $0.44-0.55$ \\
\hline $48-59$ & 1117 & 32.86 & 0.41 & $0.36-0.47$ \\
\hline $\begin{array}{l}\text { Maternal schooling } \\
\text { (years) }^{\dagger}\end{array}$ & & & $p=0.000^{*}$ & \\
\hline 0 & 950 & 57.23 & 1.39 & $1.23-1.56$ \\
\hline $1-4$ & 2370 & 52.70 & 1.28 & $1.15-1.42$ \\
\hline $5-9$ & 1345 & 49.90 & 1.21 & $1.08-1.35$ \\
\hline$\geq 10$ & 683 & 41.25 & 1.00 & Reference \\
\hline \multicolumn{5}{|l|}{ Regular income $^{\dagger}$} \\
\hline Yes & 2217 & 48.97 & 1.00 & Reference \\
\hline No & 3168 & 52.86 & 1.08 & $1.01-1.15$ \\
\hline $\begin{array}{l}\text { Household goods } \\
\text { index (tertile) }^{\dagger}\end{array}$ & & & $p=0.000^{*}$ & \\
\hline $1 \mathrm{st}$ & 1802 & 59.85 & 1.38 & $1.23-1.54$ \\
\hline 2nd & 2083 & 51.73 & 1.19 & $1.09-1.30$ \\
\hline $3 r d$ & 1512 & 43.50 & 1.00 & Reference \\
\hline
\end{tabular}

$P R$ Prevalence ratio.

$\mathrm{Cl}$ Confidence interval.

${ }^{*} x^{2}$ test for linear trend.

${ }^{\dagger}$ Variable retained for multivariate analysis.

among children in households with discontinuous electricity and drinking water originating from rivers, lakes, or open reservoirs. It was also higher in households with the predominant defecation location being outdoors in the open and in those with trash disposal by means of discarding in a river, lake, or ocean. Considering the variables related to household composition, children were more prone to have anemia if they lived in households with nine or more total residents and four or more children less than 5 years of age.

Among the maternal variables in level 3 (Table 3), maternal anemia and age were associated with the prevalence rates of child anemia, while number of children ever had was not. Children whose mothers were anemic presented a prevalence of anemia 1.35 times greater than those whose mothers had normal hemoglobin levels $\left(\mathrm{Cl}_{95 \%}\right.$ 1.26-1.44). Maternal age showed a protective effect for anemia in children, with prevalence ratio between the first (less than 20 years of age) and the last stratum (40 years and over) reaching $0.75\left(\mathrm{Cl}_{95 \%} 0.65-0.86\right)$.

Of the child characteristics presented in Table 4, birth weight did not significantly affect the occurrence of anemia, but birth in a village as opposed to in hospitals or other locations outside the village resulted in higher risk of anemia diagnosis (PR 1.23; $\mathrm{CI}_{95 \%}$ 1.12-1.36). With regard to indicators of nutritional status, anthropometric deficits measured in terms of weight-for-age, height-forage, and weight-for-height increased the prevalence of anemia (Table 4). Reports of diarrhea during the prior week also resulted in significantly greater prevalence of anemia (PR 1.32, $\mathrm{CI}_{95 \%}$ 1.21-1.43). Children who were reported to have received iron sulfate treatment or supplementation during the prior three months represented just $15.4 \%$ of the total sample and did not present lower prevalence rates of anemia than other children (PR 1.02, $\mathrm{CI}_{95 \%}$ 0.90-1.15).

Remaining in the final hierarchical model for anemia were the following variables: geopolitical region, child's sex and age, household goods index, maternal schooling, type of household flooring and roofing, source of drinking water, maternal anemia, and all anthropometric indices (Figure 1). All variables showed patterns of association consistent with those observed in the univariate analyses with the exceptions of source of drinking water and weight-for-height. In these cases, household drinking water from rivers, lakes, or reservoirs and lower weight-forheight showed protective effects for anemia.

\section{Discussion and conclusion}

The results of the National Survey reveal that more than half of indigenous children in Brazil presented anemia (51.2\%) and approximately one-sixth presented moderate/severe anemia (16.4\%). These results are similar in scale to those from the few existing epidemiological studies of anemia among indigenous children in Brazil, which highlighted the significance of this nutritional deficit in the epidemiological profile of members of localized communities, ethnic groups, and populations [10-12].

According to the results of the National Survey, the prevalence rates of anemia in indigenous children nationally were approximately double those reported for nonindigenous Brazilian children in the same age group. According to the first nationwide survey assessing the occurrence of anemia in children $<5$ years of age in Brazil, the National Survey on Demography and Health of 
Table 2 Prevalence rates of anemia among indigenous children $<60$ months according to physical, demographic, and sanitation characteristics of the household, First National Survey of Indigenous People's Health and Nutrition, Brazil, 2008-2009

Characteristic studied

N Prevalence (\%)

\section{PR}

Type of flooring ${ }^{\dagger}$

Ceramic

Cement

Wood

Dirt

Type of walls ${ }^{\dagger}$

Brick
Mud
Wood
Thatch
Canvas, plastic, or other

Type of roofing

$$
\begin{aligned}
& \text { Clay tile } \\
& \text { Corrugated sheets } \\
& \text { Wood or thatch } \\
& \text { Canvas, plastic, or other }
\end{aligned}
$$

Electricity in the home

Yes

Yes, but discontinuous

No

No. of residents in household ${ }^{\dagger}$

$$
\begin{aligned}
& \leq 4 \\
& 5-8 \\
& \geq 9
\end{aligned}
$$

No. of children $<5$ years old in household ${ }^{\dagger}$

1
2
3
$\geq 4$
fecation location
Indoor household facility
Outdoor household facility
Outdoors in the open
Other

Predominant destination of the household trash

Collected by removal service

Buried, discarded, or burned in the village

Buried, discarded, or burned outside the village

Discarded in a river, lake, or ocean

Other
44.70

60.83

56.55

1922

1863

764

1966

297

498

1558

2054

1735

42

3129

841

1414

1273

2641

1464

1885

2269

868

355

768

2719

1865

26

640

4378

305

54

10
42.74

54.44

60.46

64.71

49.54

43.60

52.34

60.87

66.34

47.56

59.70

59.14

46.01

50.84

58.63

47.63

51.33

56.95

61.67

41.26

53.33

54.07

34.10

44.00

52.22

58.17

70.91

51.72
1.00

1.15

1.56

1.45

1.00

1.27

1.41

1.51

1.16

1.00

1.20

1.40

1.52

1.00

1.26

1.24

$p=0.000^{*}$

1.00

1.10

1.27

$\mathrm{p}=0.000^{*}$

1.00

1.08

1.20

1.29

1.00

1.29

1.31

0.83

1.00

1.19

1.32

1.61

1.18
CI $95 \%$

Reference

0.99-1.34

1.29-1.89

1.23-1.72

Reference

1.12-1.45

1.24-1.62

1.28-1.79

$1.00-1.34$

Reference

1.04-1.39

1.22-1.59

1.18-1.96

Reference

1.10.-1.43

$1.12-1.38$

Reference

1.02-1.20

$1.14-1.42$

Reference

0.98-1.18

1.08-1.32

$1.12-1.49$

Reference

1.10-1.51

1.12-1.54

$0.51-1.35$

Reference

1.02-1.38

1.03-1.70

1.25-2.08

0.68-2.04 
Table 2 Prevalence rates of anemia among indigenous children $<60$ months according to physical, demographic, and sanitation characteristics of the household, First National Survey of Indigenous People's Health and Nutrition, Brazil, 2008-2009 (Continued)

\begin{tabular}{lllll}
\hline Source of drinking water $^{\dagger}$ & & & & \\
Faucet inside house & 804 & 45.87 & 1.00 & 1.13 \\
Faucet outside house & 2639 & 51.78 & 1.09 & $1.00-1.28$ \\
Shallow well & 436 & 50.23 & 1.34 & $0.91-1.32$ \\
River, lake, or reservoir & 744 & 61.55 & 1.12 & $0.13-1.59$ \\
Other & 766 & 51.17 & $0.86-1.45$ \\
\hline
\end{tabular}

PR Prevalence ratio.

$\mathrm{Cl}$ Confidence interval.

${ }^{*} \chi^{2}$ test for linear trend.

${ }^{\dagger}$ Variable retained for multivariate analysis.

Women and Children (Pesquisa Nacional de Demografia e Saúde da Criança e da Mulher - PNDS), which did not systematically include indigenous populations, the reported prevalence rates for anemia and moderate/severe anemia were $20.9 \%$ and $8.7 \%$, respectively [8]. The pattern of inequality in the occurrence of anemia in indigenous and non-indigenous children in Brazil is also quite pronounced when comparing the frequencies observed among the four geopolitical regions of the country studied in the National Survey. The prevalence ratios of anemia among indigenous and non-indigenous children $<5$ years were 1.6 in the Northeast, 4.7 in the Central-West, and 6.4 in the North. A prevalence ratio could not be calculated for the South/Southeast region because, whereas we combined the prevalence of anemia for these regions

Table 3 Prevalence rates of anemia among indigenous children $<60$ months according to maternal characteristics, First National Survey of Indigenous People's Health and Nutrition, Brazil, 2008-2009

\begin{tabular}{|c|c|c|c|c|}
\hline Characteristic studied & $\mathrm{N}$ & Prevalence (\%) & PR & $\mathrm{Cl} 95 \%$ \\
\hline Maternal age (years) $^{\dagger}$ & & & $p=0.000^{*}$ & \\
\hline$<20$ & 655 & 61.33 & 1.00 & Reference \\
\hline $20-29$ & 2759 & 50.25 & 0.82 & $0.75-0.89$ \\
\hline $30-39$ & 1541 & 50.17 & 0.82 & $0.74-0.91$ \\
\hline$\geq 40$ & 428 & 46.03 & 0.75 & $0.65-0.86$ \\
\hline Number of children & & & $p=0.829^{*}$ & \\
\hline
\end{tabular}
ever had

$\begin{array}{lllll}0-1 & 775 & 53.68 & 1.00 & \text { Reference } \\ 2 & 979 & 48.71 & 0.91 & 0.81-1.01 \\ 3 & 771 & 47.66 & 0.89 & 0.78-1.01 \\ \geq 4 & 2821 & 52.38 & 0.98 & 0.87-1.09 \\ \text { ternal anemia }^{\dagger} & & & & \\ \text { No } & 3287 & 45.62 & 1.00 & \text { Reference } \\ \text { Yes } & 2010 & 61.65 & 1.35 & 1.26-1.44\end{array}$

$P R$ Prevalence ratio.

Cl Confidence interval.

${ }^{*} x^{2}$ test for linear trend.

${ }^{\dagger}$ Variable retained for multivariate analysis.
(48.0\%), the PNDS presented them separately for the South (21.5\%) and Southeast (22.6\%) regions [8].

The geographical distribution of anemia in indigenous children reveals prevalence rates to be highest in the North (66.4\%), followed by the Central-West (51.5\%), South/Southeast (48.0\%), and Northeast (41.1\%). This notable regional difference follows a similar pattern to that observed in the National Survey for other nutritional measures, such as the prevalence of chronic undernutrition among indigenous children [20]. Additionally, indigenous households in the North region were observed to have lower sanitation, maternal schooling, and socioeconomic indicators as compared to all other regions [17]. These findings suggest that nationwide generalizations about indicators of nutritional status in indigenous children in Brazil, such as anemia and undernutrition, can conceal important regional patterns.

The notable difference in the occurrence of anemia in indigenous and non-indigenous children in Brazil documented by the National Survey finds parallel in results from other countries. Khambalia et al. [13] conducted a systematic review of the literature, identifying 50 studies published in English on the topic of anemia in indigenous peoples from 13 countries (Australia, Brazil, Canada, Guatemala, India, Kenya, Malaysia, Mexico, New Zealand, Sri Lanka, Tanzania, United States, and Venezuela). According to the authors, "the burden of anemia is overwhelmingly higher among indigenous groups compared to the general population and represents a moderate $(20-39.9 \%)$ to severe $(\geq 40 \%)$ public health problem". Also according to these authors, anemia in indigenous children is most often preventable, being associated with the promotion of food security, improved living conditions and sanitation, and the treatment and prevention of parasitic diseases such as malaria and intestinal parasites.

Presently, about 300 indigenous ethnic groups, speakers of approximately 200 distinct languages, are identified in Brazil, constituting one of the national indigenous populations with the greatest ethnic diversity in the world $[23,24]$. Because these societies are socioculturally distinct 
Table 4 Prevalence rates of anemia among indigenous children $<\mathbf{6 0}$ months according to place of delivery, nutritional status, occurrence of diarrhea, and use of iron sulfate, First National Survey of Indigenous People's Health and Nutrition, Brazil, 2008-2009

\begin{tabular}{|c|c|c|c|c|}
\hline Characteristic studied & $\mathrm{N}$ & Prevalence (\%) & PR & $\mathrm{Cl} 95 \%$ \\
\hline \multicolumn{5}{|l|}{ Place of delivery ${ }^{\dagger}$} \\
\hline Hospital & 3235 & 47.88 & 1.00 & Reference \\
\hline Village & 2141 & 58.96 & 1.23 & $1.12-1.36$ \\
\hline \multicolumn{5}{|l|}{ Birth weight (grams) } \\
\hline$\geq 2500$ & 3202 & 50.82 & 1.00 & Reference \\
\hline$<2500$ & 271 & 50.83 & 1.00 & $0.86-1.17$ \\
\hline $\begin{array}{l}\text { Weight-for-age } \\
(z \text {-score })^{\dagger}\end{array}$ & & & $p=0.000^{*}$ & \\
\hline$\geq 0$ & 1502 & 46.07 & 1.00 & Reference \\
\hline$<0$ and $\geq-1$ & 2135 & 49.29 & 1.07 & $0.98-1.16$ \\
\hline$<-1$ & 1749 & 60.28 & 1.31 & $1.21-1.41$ \\
\hline $\begin{array}{l}\text { Height-for-age } \\
\text { (z-score })^{\dagger}\end{array}$ & & & $p=0.000^{*}$ & \\
\hline$\geq 0$ & 602 & 41.00 & 1.00 & Reference \\
\hline$<0$ and $\geq-1$ & 1210 & 46.00 & 1.12 & $1.01-1.25$ \\
\hline$<-1$ & 3533 & 55.83 & 1.36 & $1.21-1.53$ \\
\hline 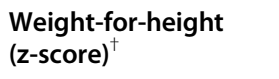 & & & $p=0.212^{*}$ & \\
\hline$\geq 0$ & 3471 & 50.84 & 1.00 & Reference \\
\hline$<0$ and $\geq-1$ & 1508 & 51.12 & 1.00 & $0.93-1.09$ \\
\hline$<-1$ & 369 & 57.16 & 1.12 & $1.01-1.26$ \\
\hline
\end{tabular}

Diarrhea during the prior week

\begin{tabular}{lllll} 
No & 3847 & 47.58 & 1.00 & Reference \\
Yes & 1509 & 63.02 & 1.32 & $1.22-1.43$ \\
sulfate use & & & & \\
Yes & 893 & 50.50 & 1.00 & Reference \\
No & 4388 & 51.30 & 1.02 & $0.90-1.15$ \\
\hline
\end{tabular}

PR Prevalence ratio.

$\mathrm{Cl}$ Confidence interval.

${ }^{*} X^{2}$ test for linear trend.

${ }^{+}$Variable retained for multivariate analysis.

from one another and from the national population, with heterogeneous forms of livelihood and social organization, the theoretical models of determination of diseases, including anemia, should be applied and interpreted with caution. Models such as those used in this paper are based in part on a set of variables, such as income and education, among others, which were originally derived from studies conducted in non-indigenous societies. Nevertheless, the use of such models for indigenous peoples in Brazil may be justified insofar as they increasingly participate in local and global markets, which in turn has important ramifications for their health, local economies, political systems, and social organizations, as is also occurring in other parts of the world $[25,26]$. Despite these caveats, the outcomes in the final models for anemia, which are discussed below, were associated with evaluated variables at all levels, as they are in many other studies on the epidemiology of childhood anemia.

The observed association between child's age and anemia has been reported in several other studies worldwide [27-29]. Children under two years of age experience high rates of growth, which increases the demand for micronutrients such as iron, folate, and vitamin $\mathrm{B}_{12}$. The introduction of foods with low iron levels during weaning and elevated frequencies of infectious and parasitic diseases among young children are also important factors in determining childhood anemia. However, the relationship between child's sex and anemia is less consistent, with some studies indicating associations between these variables $[30,31]$ and others not [32-34]. The results of the National Survey point to an association between sex and anemia in indigenous children, with greater risk among boys, although the difference was small.

With regard to socioeconomic characteristics, the results of the National Survey indicate that both maternal schooling and the household goods index, which are often considered linked to family income, were shown to be protective factors for the occurrence of anemia in indigenous children in Brazil. As is well documented elsewhere, such dimensions are intimately related to the care received by children, including nourishment and access to health services [35-38].

Concerning the physical and sanitation characteristics of households, several variables showed a protective effect against the occurrence of anemia, including type of flooring, type of roofing, and source of drinking water. The use of non-durable materials, generally of plant origin, in home construction is often interpreted in the international epidemiological literature as a reflection of unfavorable socioeconomic conditions. However, care must be taken in interpreting these results because the use of plant-based raw materials (e.g., wood or palm thatch) in indigenous communities in Brazil does not necessarily derive from monetary poverty and is often an essential component of traditional household architectural techniques, especially in rural areas [39]. Nevertheless, as previously indicated, indigenous peoples in Brazil are experiencing rapid environmental, sociocultural, and economic transformations with repercussions for the variables associated with anemia. Whereas in some parts of Brazil, especially the North region, traditional indigenous home construction techniques are widespread, in other parts of the country with longer and more widespread histories of economic development, industrialized materials often predominate [17]. This contrast suggests that at least in certain portions of Brazil, such as the 


\begin{tabular}{|c|c|c|c|c|c|c|c|c|}
\hline \multirow{6}{*}{ لَّ } & \multirow{6}{*}{\begin{tabular}{|l} 
Sex \\
Female \\
Male
\end{tabular}} & \multirow[b]{2}{*}{1.00 (ref.) } & \multicolumn{2}{|c|}{ Child's age (months) } & \multicolumn{2}{|l|}{ Household goods index } & \multicolumn{2}{|c|}{ Maternal schooling (years) } \\
\hline & & & 6 to 11 & 1.00 (ref.) & 1st tertile & $1.14(1.02-1.26)$ & 0 & $1.28(1.14-1.44)$ \\
\hline & & $1.08(1.03-1.14)$ & 12 to 23 & $0.85(0.78-0.92)$ & 2nd tertile & $1.08(0.99-1.18)$ & 1 to 4 & $1.20(1.08-1.32)$ \\
\hline & & & 24 to 35 & $0.61(0.55-0.67)$ & 3rd tertile & 1.00 (ref.) & 5 to 9 & $1.13(1.00-1.27)$ \\
\hline & & & 36 to 47 & $0.49(0.44-0.55)$ & & & $\geq 10$ & 1.00 (ref.) \\
\hline & & & 48 to 59 & $0.41(0.36-0.47)$ & & & & \\
\hline \multirow{6}{*}{ لّ } & & & \multicolumn{2}{|c|}{ Type of flooring } & \multicolumn{2}{|l|}{ Type of roofing } & \multicolumn{2}{|l|}{ Source of drinking water } \\
\hline & & & Ceramic & 1.00 (ref.) & Clay tile & 1.00 (ref.) & Faucet inside house & 1.00 (ref.) \\
\hline & & & Cement & $1.15(0.97-1.36)$ & Corrugated sheets & $1.00(0.90-1.12)$ & Faucet outside house & $0.93(0.82-1.04)$ \\
\hline & & & Wood & $1.19(1.00-1.41)$ & Wood or thatch & $1.05(0.91-1.20)$ & Shallow well & $0.84(0.70-1.00)$ \\
\hline & & & Dirt & $1.24(1.03-1.48)$ & Canvas, plastic, or other & $1.25(1.01-1.56)$ & River, lake, or reservoir & $0.80(0.68-0.94)$ \\
\hline & & & & & & & Other & $0.89(0.74-1.08)$ \\
\hline \multirow{3}{*}{ سِ } & & & & & & & \multicolumn{2}{|l|}{ Maternal anemia } \\
\hline & & & & & & & No & 1.00 (ref.) \\
\hline & & & & & & & Yes & $1.23(1.16-1.31)$ \\
\hline \multirow{4}{*}{ سّ } & & & \multicolumn{2}{|c|}{ Weight-for-age (z-score) } & \multicolumn{2}{|l|}{ Height-for-age (z-score) } & \multicolumn{2}{|c|}{ Weight-for-height (z-score) } \\
\hline & & & $\geq 0$ & 1.00 (ref.) & $\geq 0$ & 1.00 (ref.) & $\geq 0$ & 1.00 (ref.) \\
\hline & & & $<0$ and $\geq-1$ & $1.04(0.94-1.15)$ & $<0$ and $\geq-1$ & $1.11(1.00-1.25)$ & $<0$ and $\geq-1$ & $0.84(0.77-0.91)$ \\
\hline & & & $\mid<-1$ & $1.24(1.08-1.41)$ & $<-1$ & $1.17(1.01-1.35)$ & $<-1$ & $0.79(0.71-0.89)$ \\
\hline
\end{tabular}

Figure 1 Hierarchical model for anemia among children $<5$ years of age, First National Survey of Indigenous People's Health and Nutrition, Brazil, 2008-2009. Obs: Values represent prevalence ratios with confidence intervals in parentheses. Geopolitical region was included as a control variable at all levels.

South/Southeast and Northeast, the presence of traditional plant-based construction materials may indicate unfavorable socioeconomic conditions as is understood to be the case in other populations globally.

The findings of the National Survey indicate an unexpected association between anemia and domestic source of drinking water. Several studies point to the protective effect of piped water available for domestic consumption on the occurrence of anemia in Brazil and elsewhere $[40,41]$. However, the present study shows indigenous children living in households relying on drinking water from rivers and lakes to present lower rates of anemia than those in households with access to piped water. Potentially, these children may have greater access to nutrient-rich local foods than those living in household with piped water but relying on low-cost industrial foods. Analysis of this possibility is beyond the scope of the present paper and deserves further investigation.

Maternal anemia was consistently associated with the occurrence of child anemia. Mothers and children most often share a home environment, which involves mutual exposure to a common set of physical, socioeconomic, and dietary conditions. This association gains relevance when considering that the prevalence of anemia among indigenous women was $32.7 \%$, which is also extremely high [42-45]. Maternal iron deficiency is associated with low birth weight and prematurity, and there is evidence that even children born with adequate weight have diminished iron reserves when their mothers are anemic $[35,46,47]$.

Among the analyzed variables related to children, low height-for-age and low weight-for-age remained associated positively with anemia after controlling for other variables. The association between these anthropometric indices and anemia has also been observed in several other studies [41,48]. Nutritional status, as assessed by both anthropometry and hemoglobin levels, is affected by a common set of factors, including socioeconomic status, sanitation, infectious and parasitic diseases, and diet. With regard to diet, protein-energy malnutrition favors the development of anemia through a synergistic relationship. Moreover, low hemoglobin levels have been implicated in compromising linear growth $[49,50]$. It remains unclear why weight-for-height showed an inverse association in our sample. Other factors recognized as important in determining child anemia, such as gestational age at birth and birth order, were not investigated here due to the impossibility of obtaining reliable data from local indigenous health services and the limitations of our data, which were restricted to children $<5$ years [51,52].

Some limitations to this study should be taken into account when interpreting its results. The cross-sectional nature of the research design does not allow for the establishment of causal relationships. Moreover, the absence of data on infant feeding precludes analysis of dietary sources of bioavailable iron, which is important for understanding the epidemiology of anemia in the study population. The use of capillary blood instead of venous samples can constitute a source of bias due to the possibility of hemoglobin dilution with extracellular fluid through manipulation of the subject's finger at the moment the technician pricks the skin and collects the blood drop. Nevertheless, this technique offers numerous widely recognized practical advantages and does not compromise the quality of diagnosis at the population 
level $[53,54]$. Additionally, the National Survey methodology did not address the etiology of anemia. This last point deserves particular attention because appropriate population treatment measures and intervention vary according to the disease's etiology.

Iron deficiency is generally assumed to be the major cause of anemia globally [1,3]. In Brazil, dietary supplementation with iron sulfate for children between 6 and 18 months of age is a major nutritional initiative of the Ministry of Health that was implemented based on the assumption that most cases of anemia derive from dietary iron deficiency [46]. However, besides iron deficiency, other factors that may cause or be associated with anemia include nutritional deficiencies involving other micronutrients (e.g., folate, vitamin $\mathrm{A}$, and vitamin $\mathrm{B}_{12}$ ), infectious and parasitic diseases (e.g., diarrhea, malaria, and geohelminthosis), glucose-6-phosphate dehydrogenase (G6PD) deficiency, and genetically derived hemoglobinopathies $[2,27,55]$. Recent research in the western Amazonian region of Brazil indicate that about a third of anemia cases observed in a sample of non-indigenous children was not associated with iron deficiency [56]. Similarly, studies of children living in the South and Northeast regions of Brazil demonstrate that sizable rates of children suffer from anemia caused by other factors other than iron deficiency [57-59].

Given this context, deeper knowledge about the etiology of anemia in indigenous children in Brazil is essential to its proper treatment and prevention. At present, there are no studies on nutritional deficiencies among indigenous populations in Brazil that measured serum folate, vitamin $B_{12}$, plasma ferritin, or other micronutrients associated with anemia. Moreover, it is known that helminthiasis and diarrhea are highly prevalent in indigenous children in all regions of the country [60-64] and that about $70 \%$ of Brazil's indigenous population lives in regions with high risk for transmission of malaria, a parasitic disease that can be particularly acute during childhood and can cause severe anemia [65-67]. Iron sulfate supplementation or treatment with standard dosages has low efficacy where there are high levels of infectious and parasitic diseases with the potential to impact nutritional status and, more specifically, to interfere directly on hemoglobin concentrations [68-70].

In conclusion, the findings of the National Survey reported here show widespread occurrence of anemia among indigenous children in Brazil, with prevalence rates being substantially higher than those among nonindigenous children. The findings also point to regional differences in the prevalence of anemia among indigenous children, with the highest rate being observed in the North region of the country. Considering the serious consequences of anemia for child health and development, as well as the preventable nature of iron-deficiency anemia, it is necessary to develop control and prevention strategies that attend to the sociocultural and nutritional specificities of anemia in indigenous children in Brazil.

\section{Abbreviations}

Cl: Confidence interval; CONEP: National Committee on Research Ethics (Comissão Nacional de Ética em Pesquisa); FUNASA: National Health Foundation (Fundação Nacional de Saúde); G6PD: Glucose-6-phosphate dehydrogenase; PNDS: National Survey on Demography and Health of Women and Children (Pesquisa Nacional de Demografia e Saúde da Criança e da Mulher); PR: Prevalence ratio.

\section{Competing interests}

The authors declare that they have no competing interests.

\section{Authors' contributions}

AMC, CEAC, JRW, BLH, and RVS participated in the conception of the study. MSL, AMC, CEAC, JRW, PCIL, RVS, SAG, and ALE participated in data collection. MSL, AMC, ALE, BLH, and RVS performed data analysis. MSL, AMC CEAC, JRW, and RVS contributed to the interpretation of data and wrote the paper. All authors participated in the revision of the manuscript and approved the version submitted for publication.

\section{Acknowledgements}

The Brazilian Ministry of Health and the World Bank provided financial support through the Vigisus II project. Equipment was provided by FUNASA and the Escola Nacional de Saúde Pública. Support and assistance were offered by indigenous leaders and community members in all of the villages surveyed, the project's team leaders and research assistants, and the staff at local FUNASA and FUNAI offices.

\section{Author details}

'Departamento de Nutrição, Centro de Ciências da Saúde, Universidade Federal de Santa Catarina, Florianópolis, SC 88040-900, Brazil. 'Escola Nacional de Saúde Pública, Fundação Oswaldo Cruz, Rua Leopoldo Bulhões 1480, Rio de Janeiro, RJ 21041-210, Brazil. Instituto de Saúde Coletiva, Universidade Federal de Mato Grosso, Av. Fernando Correa da Costa 2367, Cuiabá, MT 78060-900, Brazil. ${ }^{4}$ Departamento de Nutrição, Universidade Federal de Pernambuco, Avenida Professor Moraes Rego 1235, Recife, PE 50670-901, Brazil. ${ }^{5}$ Programa de Pós-Graduação em Epidemiologia, Universidade Federal de Pelotas, Rua Marechal Deodoro 1160, Pelotas, RS 96020-220, Brazil. ${ }^{6}$ Departamento de Antropologia, Museu Nacional, Universidade Federal do Rio de Janeiro, Quinta da Boa Vista s/n, Rio de Janeiro, RJ 20940-040, Brazil. 'Departamento de Ciências Biomédicas, Universidade Federal de Rondônia, Rodovia BR-364 Km 9.5, Porto Velho, RO 76801-059, Brasil.

Received: 17 December 2012 Accepted: 15 May 2013

Published: 28 May 2013

\section{References}

1. Bernoist B, McLean E, Egli I, Cogswell M: Worldwide Prevalence of Anaemia 1993-2005: WHO Global Database on Anaemia. Geneva: World Health Organization; 2008

2. Milman N: Anemia - still a major health problem in many parts of the world! Ann Hematol 2011, 90:369-377

3. WHO - World Health Organization: Iron Deficiency Anaemia Assessment Prevention and Control. A Guide for Programme Managers. Geneva: World Health Organization; 2001.

4. Brabin BJ, Premji Z, Verhoeff F: An analysis of anemia and child mortality. J Nutr 2001, 131:636S-648S.

5. McCann JC, Ames BN: An overview of evidence for a causal relation between iron deficiency during development and deficits in cognitive or behavioral function. Am J Clin Nutr 2007, 85:931-945.

6. Sachdev H, Gera T, Nestel P: Effect of iron supplementation on mental and motor development in children: systematic review of randomised controlled trials. Public Health Nutr 2005, 8:117-132.

7. Monteiro CA, Benício MHD, Conde WL, Konno S, Lovadino AL, Barros AJD, Victora CG: Narrowing socioeconomic inequality in child 
stunting: the Brazilian experience, 1974-2007. Bull World Health Org 2010, 88:305-311.

8. MS - Ministério da Saúde: Pesquisa Nacional de Demografia e Saúde da Criança e da Mulher - PNDS 2006: Dimensões do Processo Reprodutivo e da Saúde da Criança, Série G: Estatística e Informação em Saúde. Brasília: Ministério da Saúde; 2009.

9. Batista-Filho M, Souza Al, Miglioli TC, Santos MC: Anemia e obesidade: um paradoxo da transição nutricional brasileira. Cad Saude Publica 2008, 24(suppl. 2):S247-S257.

10. Orellana JDY, Coimbra CEA Jr, Lourenço AEP, Santos RV: Estado nutricional e anemia em crianças Suruí, Amazônia, Brasil. J Pediatr (Rio J) 2006, 82:383-388

11. Morais MB, Alves GMS, Fagundes-Neto U: Estado nutricional de crianças índias Terenas: evolução do peso e estatura e prevalência atual de anemia. J Pediatr (Rio J) 2005, 81:383-389.

12. Mondini L, Rodrigues D, Gimeno SGA, Baruzzi RG: Estado nutricional e níveis de hemoglobina em crianças Aruak e Karibe: povos indígenas do alto Xingu, Brasil central, 2001-2002. Rev Bras Epidemiol 2009, 12:469-477.

13. Khambalia AZ, Aimone AM, Zlotkin SH: Burden of anemia among indigenous populations. Nutr Rev 2011, 69:693-719.

14. Christofides A, Schauer C, Zlotkin SH: Iron deficiency and anemia prevalence and associated etiologic risk factors in First Nations and Inuit communities in northern Ontario and Nunavut. Can J Public Health 2005, 96:304-307

15. Gessner BD: Early childhood hemoglobin level is a strong predictor of hemoglobin levels during later childhood among low-income Alaska children. Int J Circumpolar Health 2009, 68:459-470.

16. Rivera JA, Monterrubio EA, González-Cossío T, García-Feregrino R, García-Guerra A, Sepúlveda-Amor J: Nutritional status of indigenous children younger than five years of age in Mexico: results of a national probabilistic survey. Salud Publica Mex 2003, 45:466-476.

17. Coimbra CEA Jr, Santos RV, Welch JR, Cardoso AM, Souza MC, Garnelo L, Rassi E, Follér M-L, Horta BL: The First National Survey of Indigenous People's Health and Nutrition in Brazil: rationale, methodology, and overview of results. BMC Public Health 2013, 13:52.

18. Lemeshow S, Hosmer D, Klar J, Lwanga SK: Adequacy of Sample Size in Health Studies. Chichester, England: John Wiley \& Sons; 1990.

19. Ohlsson E: Sequential poisson sampling. J Off Stat 1998, 14:149-162.

20. Horta BL, Santos RV, Welch JR, Cardoso AM, Santos JV, Assis AMO, Lira PCl, Coimbra CEA Jr: Nutritional status of indigenous children: findings from the First National Survey of the Health and Nutrition of Indigenous Peoples in Brazil. Int J Equity Health 2013, 12:23.

21. Victora CG, Huttly SR, Fuchs SC, Olinto MTA: The role of conceptual frameworks in epidemiological analysis: a hierarchical approach. Int J Epidemiol 1997, 26:224-227.

22. Barros AJ, Hirakata V: Alternatives for logistic regression in cross-sectional studies: an empirical comparison of models that directly estimate the prevalence ratio. BMC Med Res Methodol 2003, 3:21.

23. IBGE - Instituto Brasileiro de Geografia e Estatística: Tendências Demográficas: Uma Análise dos Indígenas com Base nos Resultados da Amostra dos Censos Demográficos 1991 e 2000. Rio de Janeiro: IBGE; 2005.

24. Rodrigues AD: Evidence for Tupi-Carib relationships. In South American Indian Languages: Retrospect and Prospect. Edited by Klein HEM, Stark LR. Austin: University of Texas Press; 1985:371-404.

25. Brysk A: From Tribal Village to Global Village: Indian Rights and International Relations in Latin America. Stanford: Stanford University Press; 2000

26. Schröder P: Economia Indígena: Situação Atual e Problemas Relacionados a Projetos Indígenas de Comercialização na Amazônia Legal. Recife: Editora Universitária da UFPE; 2003.

27. Howard CT, de Pee S, Sari M, Bloem MW, Semba RD: Association of diarrhea with anemia among children under age five living in rural areas of Indonesia. J Trop Pediatr 2007, 53:238-244.

28. Agho KE, Dibley MJ, D'Este C, Gibberd R: Factors associated with haemoglobin concentration among Timor-Leste children aged 6-59 months. J Health Popul Nutr 2008, 26:200-209.

29. Leal LP, Batista Filho M, Lira PIC, Figueiroa JN, Osório MM: Prevalência da anemia e fatores associados em crianças de seis a 59 meses de Pernambuco. Rev Saude Publica 2011, 45:457-466.

30. Pasricha SR, Black J, Muthayya S, Shet A, Bhat V, Nagaraj S, Prashanth NS, Sudarshan H, Biggs BA, Shet AS: Determinants of anemia among young children in rural India. Pediatrics 2010, 26:e140-e149.
31. Spinelli MGN, Marchioni DML, Souza JMP, Souza SB, Szarfarc SC: Fatores de risco para anemia em crianças de 6 a 12 meses no Brasil. Rev Panam Salud Publica 2005, 17:84-91.

32. Siegel EH, Stoltzfus RJ, Khatry SK, LeClerq S, Katz J, Tielsch JM: Epidemiology of anemia among 4- to 17-month children living in South Central Nepal. Eur J Clin Nutr 2006, 60:228-235.

33. Oliveira CSM, Cardoso MA, Araújo TS, Muniz PT: Anemia em crianças de 6 a 59 meses e fatores associados no município de Jordão, estado do Acre, Brasil. Cad Saude Publica 2011, 27:1008-1020.

34. Matta IEA, Veiga GV, Baião MR, Santos MMAS, Luiz RR: Anemia em crianças menores de cinco anos que frequentam creches públicas do município do Rio de Janeiro, Brasil. Revista Brasileira de Saúde Materno Infantil 2005, 5:349-357.

35. de Pee S, Bloem MW, Sari M, Kiess L, Yip R, Kosen S: The high prevalence of low hemoglobin concentration among Indonesian infants aged 3-5 months is related to maternal anemia. J Nutr 2002, 132:2215-2221.

36. Neuman NA, Tanaka OY, Szarfarc SC, Guimarães PRV, Victora CG: Prevalência e fatores de risco para anemia no Sul do Brasil. Rev Saude Publica 2000, 34:56-63.

37. Keikhaei B, Zandian K, Ghasemi A, Tabibi R: Iron-deficiency anemia among children in southwest Iran. Food Nutr Bull 2007, 28:406-411.

38. Assunção MCF, Santos IS, Barros AJD, Gigante DP, Victora CG: Anemia em menores de seis anos: estudo de base populacional em Pelotas, Rio Grande do Sul. Rev Saude Publica 2007, 41:328-335.

39. Costa MHF, Malhano HB: Habitação indígena brasileira. In Suma Etnológica Brasileira 2: Tecnologia Indígena. Edited by Ribeiro BG. Petrópolis: Vozes; 1986:27-108.

40. Santos I, César JA, Minten G, Valle N, Neumann NA, Cercato E: Prevalência e fatores associados à ocorrência de anemia entre menores de seis anos de idade em Pelotas, RS. Rev Bras Epidemiol 2004, 7:403-415.

41. Assis AM, Barreto ML, Gomes GSS, Prado MS, Santos NS, Santos LMP, Sampaio LR, Ribeiro RC, Oliveira LPM, Oliveira VA: Childhood anemia: prevalence and associated factors in Salvador, Bahia, Brazil. Cad Saude Publica 2004, 20:1633-1641.

42. Leite MS, Santos RV, Gugelmin SA, Coimbra CEA Jr: Crescimento físico e perfil nutricional da população indígena Xavante de Sangradouro-Volta grande, Mato Grosso, Brasil. Cad Saude Publica 2006, 22:265-276.

43. Orellana JDY, Cunha GM, Santos RV, Coimbra CEA Jr, Leite MS: Prevalência e fatores associados à anemia em mulheres indígenas Suruí com idade entre 15 e 49 anos, Amazônia, Brasil. Revista Brasileira de Saúde Materno Infantil 2011, 11:153-161.

44. Souza LG, Santos RV, Carvalho MS, Pagliaro H, Flowers NM, Coimbra CEA Jr: Demography and health of the Xavante Indians from Central Brazil. Cad Saude Publica 2011, 27:1891-1905.

45. McSweeney K, Arps SA: A "demographic turnaround": the rapid growth of indigenous populations in lowland South America. Lat Am Res Rev 2005, 40:3-29.

46. Allen LH: Biological mechanisms that might underlie iron's effects on fetal growth and preterm birth. J Nutr 2001, 131(2S-2):581S-589S.

47. Scholl TO: Iron status during pregnancy: setting the stage for mother and infant. Am J Clin Nutr 2005, 81:1218S-1222S

48. Ngnie-Teta I, Receveur O, Kuate-Defo B: Risk factors for moderate to severe anemia among children in Benin and Mali: Insights from a multilevel analysis. Food Nutr Bull 2007, 28:76-89.

49. Soliman AT, Al Dabbagh MM, Habboub AH, Adel A, Humaidy NA, Abushahin A: Linear growth in children with iron deficiency anemia before and after treatment. J Trop Pediatr 2009, 55:324-327.

50. Angeles IT, Schultink WJ, Matulessi P, Gross R, Sastroamidjojo S: Decreased rate of stunting among anemic Indonesian preschool children through iron supplementation. Am J Clin Nutr 1993, 58:339-342.

51. Sinha N, Deshmukh PR, Garg BS: Epidemiological correlates of nutritional anemia among children (6-35 months) in rural Wardha, Central India. Indian J Med Sci 2008, 62:45-54.

52. Yang W, Li X, Li Y, Zhang S, Liu L, Wang X, Li W: Anemia, malnutrition and their correlations with socio-demographic characteristics and feeding practices among infants aged $0-18$ months in rural areas of Shaanxi province in northwestern China: a cross-sectional study. BMC Public Health 2012, 12:1127.

53. Patel AJ, Wesley R, Leitman SF, Bryant BJ: Capillary versus venous haemoglobin determination in the assessment of healthy blood donors. Vox Sang 2013, 104:317-323. 
54. Morris SS, Ruel MT, Cohen RJ, Dewey KG, de la Brière B, Hassan MN: Precision, accuracy, and reliability of hemoglobin assessment with use of capillary blood. Am J Clin Nutr 1999, 69:1243-1248.

55. García-Casal MN, Leets I, Bracho C, Hidalgo M, Bastidas G, Gomez A, Peña A, Pérez $\mathrm{H}$ : Prevalence of anemia and deficiencies of iron, folic acid and vitamin B-12 in an indigenous community from the Venezuelan Amazon with a high incidence of malaria. Arch Latinoam Nutr 2008, 58:12-18.

56. Castro TG, Silva-Nunes M, Conde WL, Muniz PT, Cardoso MA: Anemia e deficiência de ferro em pré-escolares da Amazônia Ocidental brasileira: prevalência e fatores associados. Cad Saude Publica 2011, 27:131-142.

57. Carvalho AGC, Lira PIC, Barros MFA, Aléssio MLM, Lima MC, Carbonneau MA, Berger J, Léger CL: Diagnosis of iron deficiency anemia in children of Northeast Brazil. Rev Saude Publica 2010, 44:513-519.

58. Assunção MC, Santos IS, Barros AJ, Gigante DP, Victora CG: Flour fortification with iron has no impact on anaemia in urban Brazilian children. Public Health Nutr 2012, 15:1796-1801.

59. Abreu MA: European conquest, Indian subjection and the conflicts of colonization: Brazil in the early modern era. GeoJournal 2004, 60:365-373.

60. Beltrame A, Scolari C, Torti C, Urbani C: Soil transmitted helminth (STH) infections in an indigenous community in Ortigueira, Parana, Brazil and relationship with its nutritional status. Parassitologia 2002, 44:137-139.

61. Brandelli CLC, Carli GA, Macedo AJ, Tasca T: Intestinal parasitism and socio-environmental factors among Mbyá-Guarani Indians, Porto Alegre, Rio Grande do Sul, Brazil. Rev Inst Med Trop Sao Paulo 2012, 54:119-122.

62. Escobar-Pardo ML, Godoy APO, Machado RS, Rodrigues D, Neto UF, Kawakami E: Prevalence of intestinal parasitoses in children at the Xingu Indian Reservation. J Pediatr (Rio J) 2010, 86:493-496.

63. Cardoso AM, Coimbra CEA Jr, Tavares FG: Morbidade hospitalar indígena Guarani no Sul e Sudeste do Brasil. Rev Brasil Epidemiol 2010, 13:21-34.

64. Orellana JDY, Basta PC, Santos RV, Coimbra CEA Jr: Morbidade hospitalar em crianças indígenas Suruí menores de dez anos, Rondônia, Brasil: 2000 a 2004. Revista Brasileira de Saúde Materno Infantil 2007, 7:281-287.

65. Cabral AC, Fé NF, Suárez-Mutis MC, Bóia MN, Carvalho-Costa FA: Increasing incidence of malaria in the Negro River basin, Brazilian Amazon. Trans $R$ Soc Trop Med Hyg 2010, 104:556-562.

66. Grenfell P, Fanello Cl, Magris M, Goncalves J, Metzger WG, Vivas-Martínez S, Curtis C, Vivas L: Anaemia and malaria in Yanomami communities with differing access to healthcare. Trans R Soc Trop Med Hyg 2008 102:645-652.

67. Souza-Santos R, Oliveira MVG, Escobar AL, Santos RV, Coimbra CEA Jr: Spatial heterogeneity of malaria in Indian reserves of southwestern Amazonia, Brazil. Int J Health Geogr 2008, 7:55

68. Allen LH, Rosado JL, Casterline JE, Lopez P, Munoz E, Garcia OP, Martinez H: Lack of hemoglobin response to iron supplementation in anemic Mexican preschoolers with multiple micronutrient deficiencies. Am J Clin Nutr 2000, 71:1485-1494

69. Cardoso MA, Scopel KKG, Muniz PT, Villamor E, Ferreira MU: Underlying factors associated with anemia in Amazonian children: a populationbased, cross-sectional study. PLoS One 2012, 7:e36341.

70. Shaw JG, Friedman JF: Iron deficiency anemia: focus on infectious diseases in lesser developed countries. Anemia 2011, 2011:260380.

doi:10.1186/1475-2891-12-69

Cite this article as: Leite et al:: Prevalence of anemia and associated factors among indigenous children in Brazil: results from the First National Survey of Indigenous People's Health and Nutrition. Nutrition Journal 2013 12:69.

\section{Submit your next manuscript to BioMed Central and take full advantage of:}

- Convenient online submission

- Thorough peer review

- No space constraints or color figure charges

- Immediate publication on acceptance

- Inclusion in PubMed, CAS, Scopus and Google Scholar

- Research which is freely available for redistribution 